\title{
Fun Speaking with Cue Card
}

\author{
${ }^{1}$ Ahmad Mursyid \& ${ }^{2}$ Fitrotul Mufaridah \\ ${ }_{1 \& 2}$ Universitas Muhammadiyah Jember \\ ('amursyid@gmail.com²mufaridah@unmuhjember.ac.id)
}

\begin{abstract}
English has become crucial to be acquired by the second or foreign language (ESL/EFL) learners to assist them with their academic life. In addition, it is essential for one to be able to speak in English. However, it is not easy for second or foreign language (ESL/EFL) learners to acquire good speaking skills. EFL learners in Asia; not to mention in Thailand are also facing similar problem. This study is aimed to how the use of cue cards as media to teach English can improve the EFL learners in Thailand. The study was conducted in one of junior high schools in Thailand. Classroom Action Research (CAR) was employed in this study. Observation and test were applied to collect the data. The result of the study revealed that this media is able to improve the speaking ability of the learners.
\end{abstract}

Keywords: students' speaking ability; cue card.

Either learning English as second or foreign language has faced almost similar problems. The ESL or EFL learners have been forced to cope with the situation where they have almost or completely different way of pronouncing words in their own languages and the one of English. As Brown and Yule (2003) mentioned that spoken language production or learning to talk in foreign language is frequently considered to be one of the most difficult aspects in language learning. This phenomenon also takes place in Thailand. This even worsened with the different alphabet they have in their language as well as the way they usually utter the sound in their language. A lot of students from the school where the study took place found that it was really difficult for them to speak in English. It was evidenced that during the teaching and learning process in the classroom, English textbook was the main source and reference in Learning English. Moreover, the teacher also used English in a very minimum rate. This has been the prior reason that the students acquired very minimum exposure of English, especially spoken English. This was also supported by the result of interview which showed that the students were seldom to use English. They rarely speak in English, and the opportunity to do it was also not much. In other words, exposure and practices were very minimum to assist them in speaking English. During the class, they were difficult to express their ideas and thoughts orally. 
To find out the students' speaking ability, the researcher held a test on their speaking competence. The result showed that the average score of the students was 53.15, and it was only $36.84 \%$ of the students, or about 6 out of 15 students who got the score $>53.15$. It means that they have not reached the passing grade which was $>60$. In short it can be said that their speaking ability was still low, and therefore needed to be improved.

To improve the students' speaking ability, students' activeness is also demanded to be increased as well. In doing so, the English teacher is demanded to be creative to encourage the students to speak more in English during the class. One of the ways is to employ the use of media in teaching and learning process. Media mediates communication in learning; it mediates the communication between teacher and students (Heinich, 2002). As he stated in his book that media means a channel which carries a message or information between the source and receiver. In this case, the teacher acts as the source and the students are the receivers. They receive the message or information from the media provided by the teacher. In the teaching and learning process, media has a crucial role, one of which is to attract the students' attention or even motivate them in learning. Visual media is one among several types of media. It can stimulate vision or sight of the students during the learning process.

In this study, the researcher employed one of the visual media in the teaching and learning process. He employed cue cards. Cue card is a card with words or pictures on it. Harmer (2001) proposed that cue cards can be used to encourage the students to respond in pair work activities. In addition, cue card which is the modification of pictures has a lot of advantages; one of which is that the picture on the cards is clearly visible, so that the students are able to see it clearly. Consequently, it can help them to use the picture on the card as the cues or clues for them to speak. Wright $(1989$, p. 17) added that picture can stimulate and provide information to be referred to in conversation, discussion and storytelling. It means cue card with picture on can make the students speak more easily from what they see on the picture.

The aforementioned background has been the reason to take a study on the use of cue cards to improve the EFL learners' speaking ability in one junior high school in Thailand.

\section{Method}

The study employed classroom action research (CAR). This research comprises five steps (Arikunto, 2010). The first is preliminary study. It was done through classroom observation and pre- test to know the initial stage of the students' speaking ability. This was done also by interviewing the English teacher in related to the teaching and learning activities and media used in the teaching and learning process. It was then followed by planning, acting, observing and evaluating, and the last is reflecting. The subjects of the research were the eleventh grade students at Muslim Suksa School Yala Thailand in 2014-2015 Academic Year which was consisted of 15 students.

Observation and speaking test were used to collect the data of the study. In the speaking test, students were given topic about animals. They were asked to give some information about animals by describing it. The aspects being scored covered fluency, grammar, pronunciation and vocabulary.

The observation was focused on the indicators of students' performance in term of their activeness during the teaching and learning process. An observation checklist was implemented during the observation. The students were observed based on numbers of indicators adopted from Elliot (2001) to inform how active or passive they were during the teaching and learning process. The indicators are whether they were (1) paying attention to the teacher, (2) asking questions to the teacher lesson, (3) answering questions given by the 
teacher, and (4) performing the task during the lesson or not. The students will be categorized active if at least has fulfilled three indicators.

\section{Results and Discussion}

The study employed Classroom Action Research (CAR) which has two cycles. Each of the cycles covered three meetings with 80 minutes duration in every meeting. In meeting three of each cycle, a speaking test was held to know the students' speaking ability. In each of the test, the students were asked to describe pictures which have been prepared by the researcher who acted as the teacher during the study.

During the process of teaching and learning the researcher applied the use of Cue Card was applied in teaching speaking. The pictures on the cue card were about animal and things. The students were give sets of vocabulary related to the pictures on the cue cards. During the lesson, the students were grouped. Set of cue cards was provided for each group. The students were instructed to have a guessing game with the cards. One group came forward and each member of the groups gives at least 3 sentences as clues to another group, the other groups had to guess the picture on the cue card by raising their hands. This was done in the first meeting.

In the second meeting, the use of Cue Card was applied in the teaching speaking. The pictures on the cue card were about person. Some vocabulary related to the picture on the cue cards was given to the students. This time, they were not put into groups, but were set to work in pairs. The teacher distributed the cue cards to each pair. They were asked to describe the cue cards with the partner and present it orally the description in front of the class. In the third meeting of this cycle, the speaking test was given to the students. In the test, students had to describe the pictures prepared by the teacher. They were asked to choose the picture and have a guessing game with their partner based on the picture they have chosen.
In the first cycle, in meeting one, the use of Cue Card was applied in the teaching speaking. The pictures on the cue card were about person. List of vocabulary was displayed on the board and students were asked to read them aloud. The teacher helped them with the pronunciation and the meaning of words in the vocabulary list. They were then divided into group. Set of cue cards was given to the groups. Before starting the guessing game, the teacher explained the rules of the game once more to remind the students on how to have the game. This time, one group came forward. They were given time to prepare in giving the clues. Each group member had to come up with at least one clue in the form of a sentence, so there were at least five sentences for the cue cards. Meanwhile the other groups were obliged to answer what is on the cards based on the given clues. They had to raise their hands to get the turn to answer what is on the cards. In the second meeting, the use of Cue Card was applied in the teaching speaking. The pictures on the cue card were about animal and thing. Then, some new vocabulary related to the topic were given to the students, then they were drilled. In this meeting they were paired. Each pair was given the cue cards; one student got one cue card. Afterward, they had responsibility to provide description for the picture printed on the cards. They were working with their partner. When one asked or provided clues for the picture, another one tried to guess what picture was on the card. They had to perform the "clues giving" and "guessing" in front of the class with their partner. In the third meeting, a speaking test was given.

The study resulted differently. In term of students' activeness, the first cycle showed that $59.35 \%$ of the students were active and $40.65 \%$ were not active. While their average score showed that $52.63 \%$ of the students got score below 70. In the second cycle, the activeness of the students has increased $19.01 \%$; it became $78.36 \%$ of the students were active during the class activity in speaking English. The rest of 
the students, $21.64 \%$ were passive. The students who got score $\geq 70$ were also increased from $52.63 \%$ into $73.68 \%$.

Based on the research result of speaking test and observation, it was found that there was a gradual improvement on the students' speaking ability from the preliminary study to the second cycle. In the preliminary study, it showed that the students' speaking ability before being given the action by teaching speaking using cue card was unsatisfactory yet. It was found that the result of mean score was 52.89 and the percentage of requirement of speaking ability was $36.84 \%$. It can be concluded that the students' speaking ability was still low. The students were not active in expressing their thoughts, opinions and ideas through speaking English. It is caused by lack of opportunity to practice in the class.

In the first cycle, some students got difficulty in giving the clues in playing guessing game by using the media of cue card, because there was no preparation. Moreover, the students didn't have enough vocabulary so they had difficulties in giving clues and describing cue card with a partner about the picture on the cue card. They were not used to practice their speaking.

From the reasons above, the action in the second cycle needs to be modified by giving time to prepare to create clues, giving more new vocabulary and drilling with the vocabulary together and giving more practice to the students.

In the second cycle, the students were given time in preparation and more practices because speaking needs opportunity in practicing to speak well. This is in line with what have been stated by Brown, Anderson, Shill Cock and Yule in Newton, J and Nation (2008) that the learners should have the opportunity to work through a series of spoken tasks that gradually increase in complexity. By having more practice in speaking, the students are expected to be able to speak English well. In addition, more new vocabulary about the picture were given vocabulary is another language element required in speaking. It means that having enough exposure of vocabulary on the target language can help learners to have a better opportunity to make use the language with the help of the new words or expression in the vocabulary. This is proposed by Wilkins in Walter $(1997$, p. 5) "the fact is that without grammar very little can be conveyed, and without vocabulary nothing at all can be conveyed. This statement strengthened the idea that vocabulary is crucial in a foreign language learning, especially in learning to speak the language.

\section{Conclusion}

Learning a foreign language, especially learning to speak requires teachers to have creativity to help learners to be active and motivated in learning. Having a media in teaching can help teachers and learners to get engaged in an effective and interactive communication during teaching and learning activities. Using cue cards as media in teaching speaking can both activate and assist learners during the learning process. It helps learners to create clues to compose a simple conversation on a topic. The pictures provided in the cue cards help learners to the idea of what to be learned. This study has proven that cue cards can lead to a more effective, interactive and enjoyable learning; especially in learning English as a foreign language.

\section{References}

Arikunto, S. (2010). Prosedur Penelitian Suatu Pendekatan Praktik. Jakarta: Rineka Cipta.

Brown, H.G. (2003). Language Assesment Principles and Classroom Practices. United States: San Fransisco State University. 
Elliot, John. (1991). Action Research for Educational Change. Ballmoor: Open University Press.

Harmer, Jeremy. (2007). The Practice of Language Teaching (4th Edition). Edinburg: Pearson Education Limited.

Heinich, R., Melenda,M., Russel, J.D., and Smaldino, S.E. (2002). Instructional Media and Technologies for Learning (7th Edition). New Jersey: McMillan Publishing Company.

Newton, J and I.S.P Nation. (2008). Teaching ESL / EFL Listening Speaking. New York and London: Rouletdge, Taylor and Francis Group

Wright, A. (1989). Pictures for Language Learning. Cambridge: Cambridge University Press.

Walter, G. (1997). The Elements of Foreign Language Teaching. United Kingdom: Multilingual Matters. 